\title{
電極表面の非線形現象
}

\author{
中林誠一郎・宮北康之・Antonis KARANTONIS \\ 埼玉大学理学部基礎化学科③38-8570 埼玉県さいたま市桜区下大久保 255
}

（2003 年 10 月 2 日受理）

\section{Nonlinear Dynamics at Electrochemical Interfaces}

\author{
Seiichiro NAKABAYASHI, Yasuyuki MiYAKITA and Antonis KARANTONIS \\ Department of Chemistry, Faculty of Science, Saitama University \\ 255 Shimo-okubo, Sakura-ku, Saitama 338-8570
}

(Received October 2, 2003)

\begin{abstract}
Some electrochemical reactions spontaneously oscillates and forms a pattern on the electrode surface. These are caused by the non-linearity embedded in the reaction. We are interested in these phenomena in electrochemistry in terms of analogy between coupled electrochemical oscillators and neural oscillators, and synthesis of functional materials utilizing selforganization. In this article, we will present some of our recent works on the topics of (1) collective behaviors of coupled electrochemical oscillators and their analogy to neural network, (2) spontaneous synthesis of one dimensional layered nanostructures of copper metal and cuprous oxide, and (3) formation of a quantum contact through which the electronic conductance is quantized by $2 e^{2} / h$.
\end{abstract}

\section{1. は じめに}

自然界や生命系では，エネルギーを消費しながら規則 的なリズムや空間パターンなど秩序構造を作り出す仕掛 けを数多く見出すことができる。また電気化学における 固液界面も, 散逸構造の宝庫である ${ }^{1,2)}$ 。これは, ここ が電気エネルギーと化学エネルギーの交換が起こり, さ らに物質の出入りが進む開かれた非平衡な反応場である からである。われわれが手がけた, いくつかの電極界面 に現れる空間規則的なパターンを Fig. 1，2 に示す。

Fig. 1 は $100 \mathrm{~mm}$ の隙間を電解溶液で満たし, 電気化 学的な RB 対流を駆動した結果（レーザー干渉像）と, その計算シミュレーションである3)。計算結果は非線形 流体力学を電気化学境界条件のもとで解いて得た。Fig. 2 は, 銀とアンチモンを同時に電解析出させると, 電極 表面にできる $10 \mathrm{~mm}$ サイズの模様である。あたかも, 蚊取り線香のような幅一定の螺旋波が, 電極表面を動き, 衝突と干渉を繰り返すダイナミクスを眺めることができ $た^{4,5)}$ 。

E-mail: sei@chem.saitama-u.ac.jp
これらの仕事を通して, われわれはゆっくりと非線形 現象の理解を深めると同時に, 応用の可能性のある「リ アリティ」を当該分野に持ち込みたく願った。本稿では 非線形電気化学における「複雑系の数理」( 8) から「物理 化学的な機能物質合成 $\rfloor^{9 \sim 11)}$ まで, 我々が近年行った研 究を紹介したい。

\section{2. 電気化学振動子の集団挙動と神経系ネッ トワークとの相関}

硫酸水溶液に鉄線を漬け，対極との間の電位を規制す ると, 電流が自発的にパルス化する。これは, 鉄電極表 面の不導体皮膜の生成崩壊を反映した非線形自励発振現 象である。酸化皮膜の安定性は, 水素イオン濃度と電位 の 2 変数で書き下すことができる。表面から多量の鉄イ オンが放出されると（電流パルス）, 生成した空間電荷 によって移動度の一番大きな水素イオンが弾き飛ばさ れ, 電極表面の $\mathrm{pH}$ が増加する。アルカリ域では酸化膜 の安定性が高まるので, 電極表面が皮膜で覆われ電流が 止まる。すると, 水素イオンが表面に戻り, 酸化皮膜が 不安定化し再び電流が流れる。この双安定な状態を交互 に繰り返して，鉄電極の自励発振は進行する ${ }^{8)}$ 。 
(a)

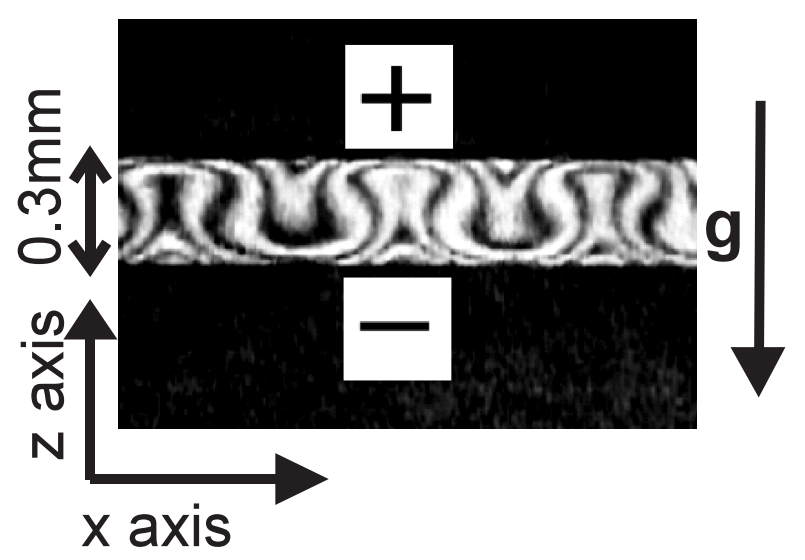

(b)

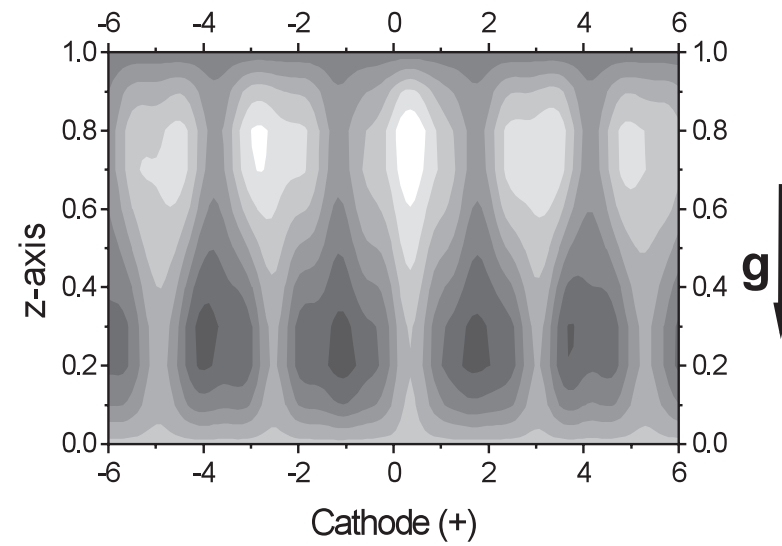

Fig. 1. The electrochemically driven Rayleigh-Bénard convection. (a) Vertical cross sectional view of the concentration of the copper sulfate obtained by the laser interferometer. (b) Theoretical result.

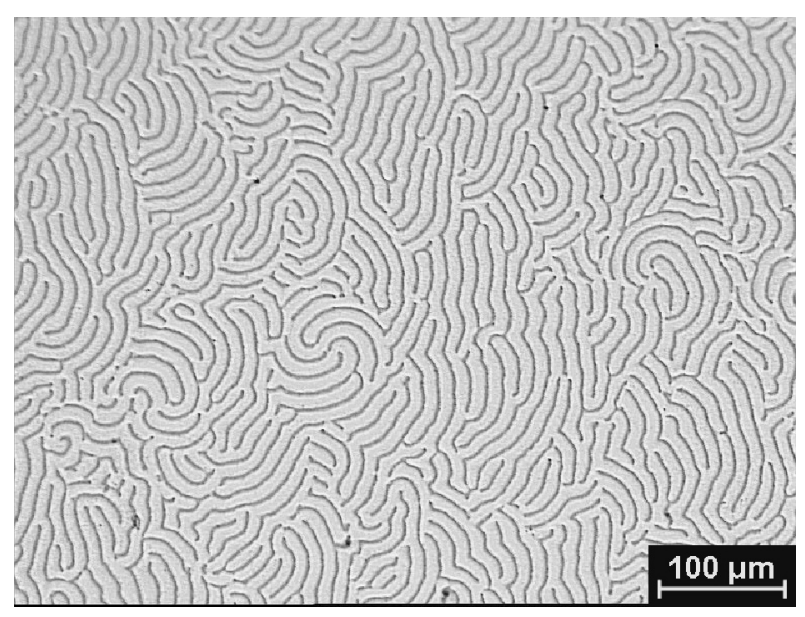

Fig. 2. Spatiotemporal pattern formed by $\mathrm{Ag} / \mathrm{Sb}$ coelectrodeposition.

この電気化学振動子を同一の電解液中で複数個並べる と，それらは相互に影響し合いながら時間的・空間的な (a)

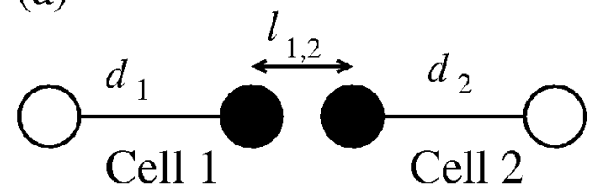

(b)

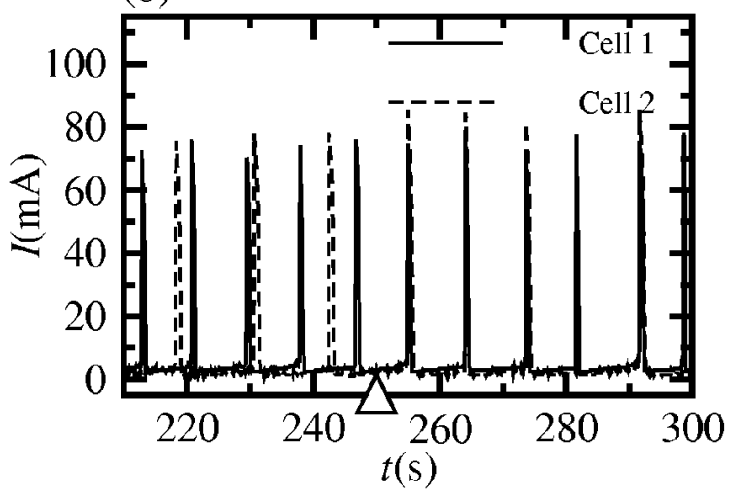

Fig. 3. (a) Two coupled non-linear electrochemical oscillator pairs in line arrangement, with two interacting anodes (black circles) and (b) time course to synchronization through transition.

秩序構造を作り上げて行く12,13)。このとき振動子は，溶 液を介して互いの電流パルスを促す興奮性の結合や電流 パルスの発生を抑える抑制性の結合によって結ばれてい る。この振動子間の結合は電気化学系の電極の並べ方に より任意に定めることができる。

Fig. 3 に, 興奮性の結合で結ばれた 2 つの電気化学振 動子の応答を示す。邪魔板が扱まれている間は, 相互作 用が妨げられるために，それぞれの振動子は周期と位相 をずらして勝手に発振している。 $t=250 \mathrm{~s}$ で邪魔板を除 くと, 直ちに相互作用し, 次の電流パルスからリズムと 位相を揃え同期した。同期状態では, 独立に発振してい るときに持っていた各々の振動子固有の周期および位相 の違いは完全に補償され, 振動子は共通のリズムで位相 を合わせて発振している。このように興奮性の結合で結 ばれた系では, 個々の振動子の固有周期に大きな違いが あるにもかかわらず，速やかに同期に達するということ がわかる。この同期の特徵は神経生理系の結合振動子の 分野で発展してきた理論と非常によく一致する。

次に, 電極の並べ方により制御される興奮性および抑 制性の結合を組み合わせた，24 個の星型に並べられた 電気化学振動子のネットワークの応答を Fig. 4 に示す。 各点に配置された振動子が, 電流パルスを放出して, そ れらが電解液の中で相互に干渉しあい，振動子集団の時 間と空間域におけるパターンを生成する。この時空間関 係をマップするために，Fig. 4 では各振動子の電流の大 


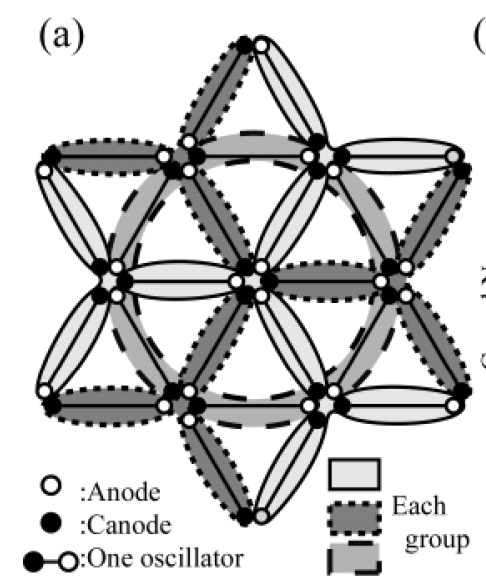

(b)

(c)
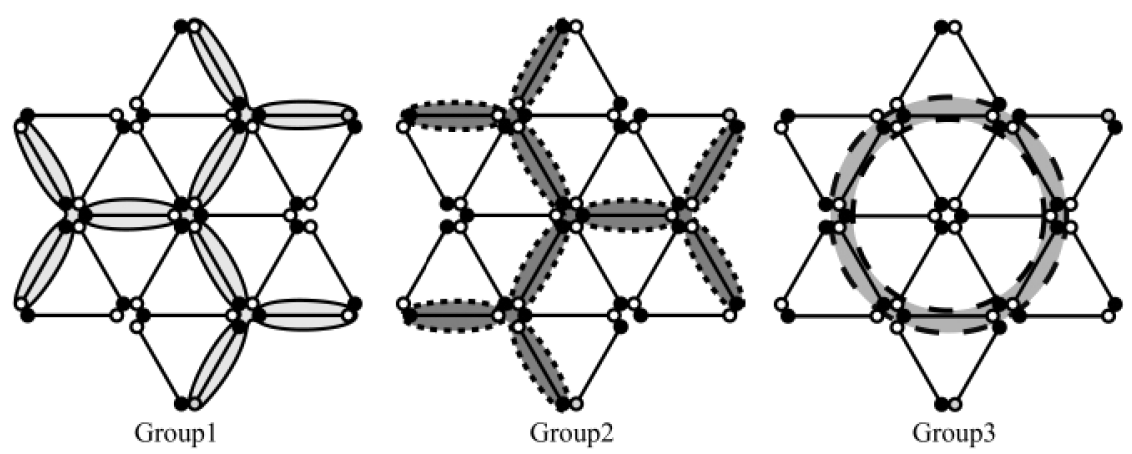

Fig. 4. Collective behavior of assembly of electrochemical oscillators (a) Star set with 13 nodes $(N=24)$, (b) Spatiotemporal response for the star configuration, (c) Schematic view for the grouping.

きさに応じて色調を変化させている。この星型の電極配 置では, 振動子集団は 3 グループに分割され発振する。 ひとつの集団内では興奮性の刺激によって結合し合い, グループ間は抑制性の結合によって結ばれている。

このように, 連成電気化学振動子は神経生理系の振動 子ネットワークの多くの特徵を模擬することができ

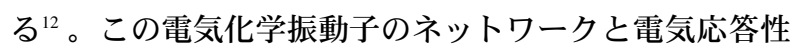
ケモメカニカルシステム ${ }^{14)}$ を組み合わせると, あたかも 散在神経系の生物であるクラゲの傘の開閉運動が神経の 配置により自動的に生み出されるように, 非線形振動子 のネットワークによって運動が制御される, 生物に類似 したシステムを人工的に作り上げることができるのでは なかろうか。

非線形を含む反応論の視点で生物を眺めると, 形態形 成におけるチューリング機構, 界面化学や電気化学さら には光化学を利用した検出・制御系など, 生物は, あり とあらゆるメカニズムを総動員して機能を発現させてい ることに驚く。これらのうち, 例えば, 神経伝播のホジ キンス・ハックスレー機構など, 生物は, 多くの場合, 非線形性を巧みに取り入れている。非線形性を取り込む ことにより, 時空間域での秩序形成機能力と, 外乱に対
するロバストネスが獲得されているのではなかろうか。 また, 均一系の化学振動系としてしばしば用いられる CSTR（連続流通鯢汼反応槽）で駆動された BZ 系 ${ }^{15}$ で は, 事実上, 数組の振動子の連成が上限であるが, 電気 化学振動子系は, 連成の上限に関する実験的な制約がな いため, このことをモデル的に検証し得る数少ない実験 系であるといえる。

\section{3. 電子・光デバイスの化学合成}

鉄非線形電気化学振動子は, 鉄電極が自身を溶かしな がら作り上げる散逸構造であった。もし, 金属が析出す る反対向きの反応に双安定性を組み込むことができれ ば，電極表面に規則正しい構造を積み上げることができ るだろう。私たちは, 具体的な成果として, (a) 数ナノ メータからサブミクロン周期でバンド幅が変調された積 層構造を自動合成する反応を研究し, 電子正孔の量子封 じ込め効果により, 負性抵抗機能や構造色が発現するこ とを示した。(b) 原子が数個数珠繋ぎに列んだ橋で, 2 つの導体を繋ぐ反応を開発し, 電気伝導度が量子化され ることなどを明らかにしてきた。これらの電子や光の機 能を支える特異な構造は, 自励発振現象や自己組織化反 
応を巧く利用すると, ワンポットで自動的に「物理化学 的に合成」できる。この経験をさらに系統的に発展させ， 量子効果や光学機能を有する特異な空間周期パターンを 持つ人工的な機能物質群を自動合成する機構を系統的に 探索したい。そして, 非線形電気化学反応を「電子・光 デバイスを化学合成する」新技術として完成させること を目指したい。本節では, 1 次元超格子とコンダクタン スが量子化された量子接点の化学的合成に関する例を紹 介する。

数多くの電気化学振動系のなかで, 「乳酸 $/ \mathrm{CuSO}_{4} / \mathrm{Cu} 」$ 系は極めて特異である。第一に, 還元過程の自励発振で あるため, 反応後の電極表面には電解生成物が蓄積され る。この反応はミズリーロラー大学 Switzer らにより発 見された反応系である ${ }^{(6)}$ 。数十周期振動を経験した電極 を引き上げ, 表面から深さ方向にスパッタしながら組成 を分析すると, $\mathrm{Cu}_{2} \mathrm{O}$ と $\mathrm{Cu}$ の層が交互に積み重なった 層状構造が観測される。 $\mathrm{Cu} / \mathrm{Cu}_{2} \mathrm{O}$ 構造を $2 \mathrm{~nm}$ 周期で積 み上げ, 面に直行する向きで電流電位関係を測定すると, 正孔の量子閉じこめ効果に起因する負性抵抗を室温で測 定できた。私たちは, この報告を手本にして, 非線形電 気化学の物作りとしての可能性を検討した。

「乳酸 $/ \mathrm{CuSO}_{4} / \mathrm{Cu}$ 系は, 原理的に新しい機能物質合 成法を示唆した重要な反応系ではあるが，改良すべき点 も多い。 $\mathrm{Cu} / \mathrm{Cu}_{2} \mathrm{O}$ 積層超格子の析出層の形成を表面選 択的な 2 次高調波発生 (SHG) 分光で評価した我々の結 果について述べる ${ }^{911}$ 。Fig. 5 は, 実験と結果の概要を 示した図である。予備的な測定から, 自励発振をおこな っている電極上には, 発振に同期して金属銅と酸化銅が 交互に積み上がっていくことがわかった。この時, 析出 層の形態と最外層の光学的性質の交代を評価する目的 で, 2 次の非線形光学効果と AFM で測定した表面モル

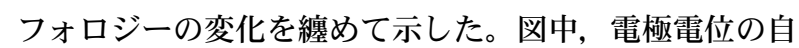
励発振（実線）は明膫に観測されるものの, 2 次高調波 発生強度の時間変化 (点線) は, 必ずしも明瞭な振動波 形を示さない。積層系は SHG 活性な反転対象性を有さ ない界面を多数含むので, 2 次高調波 $(2 \omega)$ 相互の光 干渉を考えに入れて結果を解釈する必要がある。図中, 10 周期までは, 妥当なパラメー夕を用いて $2 \omega$ 干渉モ デルで説明できるが, さらに積層が進んだ状態では, SHG 信号の変化を説明し得ない。そこで, 反応の各時点で測 定した AFM 像を見ると, 電極表面にカリフラワー状に 超微粒子（直径 $10 \mathrm{~nm}$ 程度）が析出していた。この事 実を総合すると, 基板表面への析出は, 原子的に均一な 析出形態ではなく, 銅微粒子と酸化銅微粒子が交互に積 み上がった切れの悪い積層膜が生成していることが明ら かである。このことは, 非線形電気化学法により合成さ れた周期構造を, 電子材料へ応用するためには, 析出層 の原子レベルでの構造制御（ヘテロエピなど）が, 必須 であるといえる。

最後に, コンダクタンスが $2 e^{2} / h$ で量子化された量子 接点の化学的合成を試みたのでこれについて述べる。

Fig. 6 は，典型的な 2 次元フラクタルである。これは, お互いに混じり合わない油と水との界面に, 電気化学的 に金属亜鉛を局在析出させて作った ${ }^{17,18)}$ 。これらの絵に 描いたような空間模様は，はじめは応用の方途がほとん どないと思っていたが, 最近, 2 次元フラクタルの衝突 を利用して, 電気伝導度が量子化される量子金属接点が 簡単にできることを見いだした ${ }^{18)}$ 。

4-メチル 2-ペンタノンと硫酸亜鉛水溶液の液液界面に 置かれた作用電極をカソード分極すると，金属樹が物質 輸送に支配されながら界面選択的に析出し, 針状の枝葉 を無数に持つ 2 次元フラクタルが成長する。このとき,

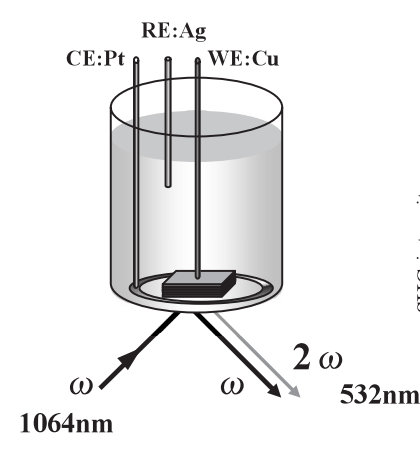

(a)

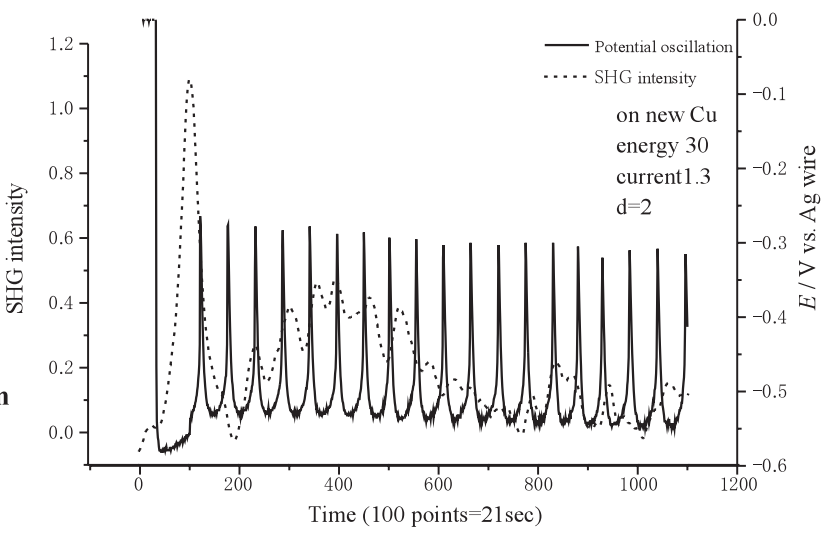

(b)

Fig. 5. Electrochemical and $\mathrm{SHG}$ responses in spontaneous growth of $\mathrm{Cu} / \mathrm{Cu}_{2} \mathrm{O}$ super lattice (a) Scheme of experimental set-up, (b) Time course of potential oscillations and SHG at reacting interface. 


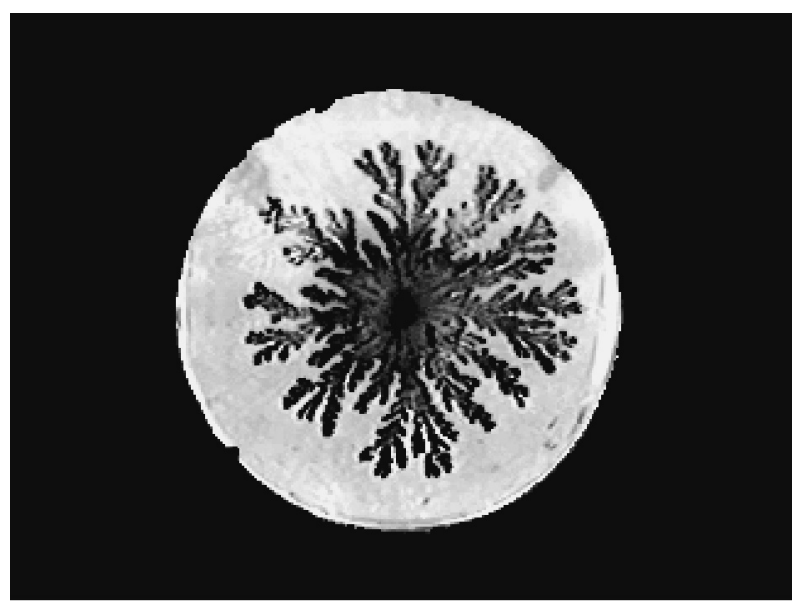

Fig. 6. Quasi-two dimensional zinc fractal at liquid/liquid interface.

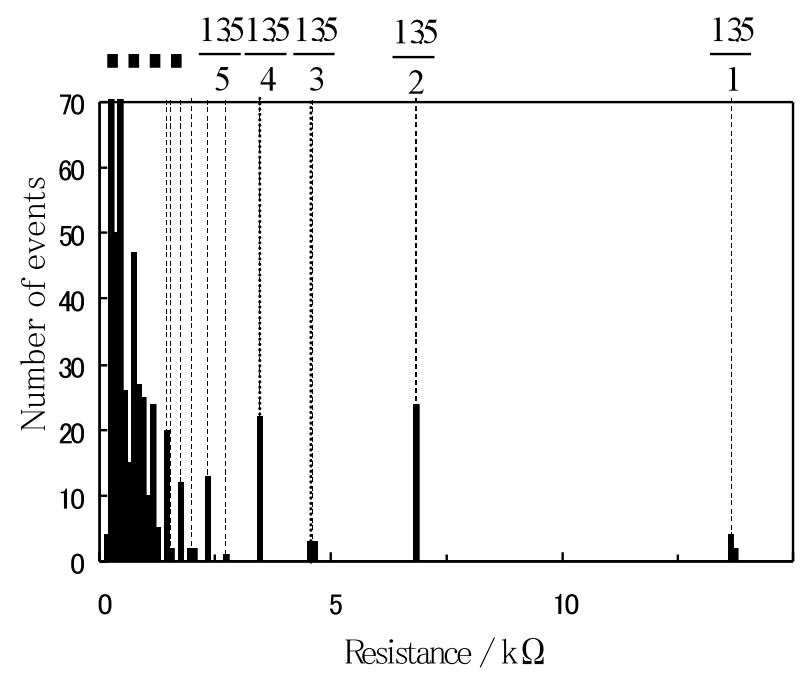

Fig. 7. The histogram of the number of the events when each differential resistance was obtained. The harmonics $(13.5 / \mathrm{N} \mathrm{k} \Omega)$ were shown above.

作用極の周りを銅板でぐるりと囲み，銅電極に流れ込む 電流を観測したところ, 亜鉛フラクタルと銅板の衝突後, 階段状に電流值が変化することに気が付いた。2つのバ ルク金属間を原子で結んだ架橋構造は量子的な電子輸送 を示す量子接点となる。理論に拠れば，階段電流が観測 されるときの量子化された抵抗值は $\mathrm{h} / 2 e^{2}=12.9 \mathrm{k} \Omega$ と なるはずである。観測された階段電流から見積もった抵 抗值をカウントし, ヒストグラムで表したものが Fig. 7 である。階段一つ当たりの電流值に対応する抵抗值は $12.9 \mathrm{k} \Omega$ ではなく $13.5 \mathrm{k} \Omega$ であった。ヒストグラムは $13.5 / \mathrm{N} \mathrm{k} \Omega(\mathrm{N}=1 ， 2 ， 3 \cdots)$ にピークを持ち，これは $\mathrm{N}$ 個の接点を持つことを意味する。 $12.9 \mathrm{k} \Omega$ と $13.5 \mathrm{k} \Omega$ と いう抵抗值の実測值と理論值の違いに対する答えは今の 時点でははっきりしていない。しかし， $12.9 \mathrm{k} \Omega$ という
抵抗值が一般的に見られる $\mathrm{sp}$ 金属と $\mathrm{d}$ 金属との間にし ばしば相違が見られることを考え合わせると，この違い は带鉛原子の電気的特性によるものである可能性があ る。

これまで，この量子接触を作成する試みでは，STM を用いて金基板と探針との間に金のナノワイヤを形成さ せたり，機械的にギャップを作る $\mathrm{MCB}$ 法など，大掛か りな装置によって実現されてきた。このフラクタル法は, 量子デバイスのビーカーの中での物理化学的合成という 屝を開くはじめの一歩になると信じている。

\section{4. おわりに}

非線形性は，身の回りの自然を理解する上で普遍的な 機構であるにもかかわらず，これを対象とした研究の歴 史は意外に浅い。これは，非線形性がもたらす複雑で豊 かな諸側面を切り捨て，学問が取り扱い容易な客観世界 に安住してきたデカルト以来の自然観の歪みかもしれな い。我々は，非線形をキーワードにして，強磁場中にお ける非線形系の振る舞いや，散逸系である電極表面での パターン形成を，非線形レーザー分光や強磁場，顕微分 光法を駆使して研究してきた。今後の研究方向を縓める と, 非線形過程を「機能物質合成」と「情報処理」へと 発展させたい。さらには，この2つを融合させ，あたか も生物が子供を作るように, 機能物質のナノ構造をコピ 一したり，或いは，環境に合わせて進化させる自動化学 機構を創製することを現実可能な夢として, 光・電気・ 強磁場技術を組み合わせ合理的に研究を建ち上げて行き たい。

\section{文献}

1) J.L. Hudson and T. T. Tsotsis: Chemical Eng. Sci. 49, 1493 (1994).

2) K. Krischer: J. Electroanal. Chem. 501, 1 (2001).

3) S. Nakabayashi, K. Inokuma and A. Karantonis: Phys. Rev. E. 59, 6599 (1999).

4) S. Nakabayashi, I. Krastev, R. Aogaki and K. Inokuma: Chem. Phys. Lett. 294, 204 (1998).

5) S. Nakabayashi, K. Inokuma, A. Nakao and I. Krastev: Chem. Lett. 88 (2000).

6) A. Karantonis and S. Nakabayashi: Chem. Phys. Lett. 347, 133 (2001)

7) A.Karantonis, L.Bieniasz and S.Nakabayashi: PCCP. 5, 1831 (2003).

8) Y. Shiomi, A. Karantonis and S. Nakabayashi: PCCP. 3, 479 (2001).

9) S. Nakabayashi and K. Nagai: Trans-MRSJ 25, 119 (2000).

10) E. Mishina, K. Nagai and S. Nakabayashi: Nano. Lett. 1, 
401 (2001).

11) E.D. Mishina, K. Nagai and S. Nakabayashi: PCCP. 4, 127 (2002).

12) A. Karantonis, Y. Miyakita and S. Nakabayashi: Phys. Rev. E. 65, 046213 (2002).

13) Y. Miyakita, A. Karantonis and S. Nakabayashi: Chem. Phys. Lett. 362, 461 (2002).

14) Y. Osada, H. Okuzaki and H. Hori: Nature 355, 242 (1992).

15) I.R. Epstein and J.A. Pojman: "An Introduction to Non- linear Chemical Dynamics" (Oxford University Press, New York, 1998).

16) J.A. Switzer, C.-J. Hung, L.-Y. Huang, E.R. Switzer, D. R. Kammler, T.D. Golden and E.W. Bohannan: J. Am. Chem. Soc. 120, 3530 (1998).

17) S. Nakabayashi, R. Aogaki, A. Karantonis, U. Iguchi, K. Ushida and M. Nawa: J. Electroanal. Chem. 473, 54 (1999).

18) S. Nakabayashi, H. Sakaguchi, R. Baba and E. Fukushima: Nano. Lett. 1, 507 (2001). 